NASA Technical Memorandum 105307

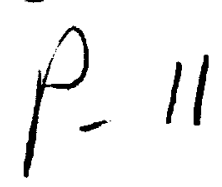

\title{
Multi-Megawatt Inverter/Converter Technology for Space Power Applications
}

Ira T. Myers and Eric D. Baumann

National Aeronautics and Space Administration

Lewis Research Center

Cleveland, Ohio

Robert Kraus

W.J. Schafer Associates, Inc.

Arlington, Virginia

and

Ahmad N. Hammoud

Sverdrup Technology, Inc.

Lewis Research Center Group

Brook Park, Ohio

Prepared for the

Ninth Symposium on Space Nuclear Power

sponsored by the Institute for Space Nuclear Power Studies,

University of New Mexico

Albuquerque, New Mexico, January 12-16, 1992

\section{N/Sก}

$(4 A S A-T Q 105307)$ HULTI-AGABATT

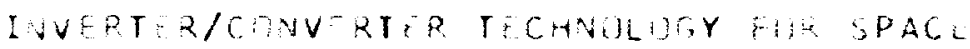

DNS APPLICATIOVS (UA34) Ui O ESCL 100 


\title{
MULTI-MEGAWATT INVERTER/CONVER'TER \\ TECHNOLOGY FOR SPACE POWER APPLICATIONS
}

Ira T. Myers and Eric D. Baumann

National Aeronautics and Space Administration

Lewis Research Center

21000 Brookpark Road

Cleveland, $\mathrm{OH} 44135$

(216) 433-6116 (216) 433-6113

FTS 297-6116 FTS 297-6113

\author{
Robert Kraus \\ W.J. Schafer Associates, Inc. \\ 1901 N. Fort Myer Drive \\ Arlington, VA 22209 \\ (703) 558-7900
}

\author{
Ahmad N. Hammoud \\ Sverdrup Technology, Inc. \\ Lewis Research Center Group \\ Brook Park, OH 44142 \\ (216) 433-8511 \\ FTS 297-8511
}

\begin{abstract}
Large power conditioning mass reductions will be required to enable megawatt power systems envisioned by the Strategic Defense Initiative, the Air Force and NASA. Phase I of a proposed two phase interagency program has been completed to develop an $0.1 \mathrm{~kg} / \mathrm{kW}$ DC/DC converter technology base for these future space applications. Three contractors, Hughes, General Electric (GE), and Maxwell were Phase I contractors in a competitive program to develop a megawatt lightweight DC/DC converter. Researchers at NASA Lewis Research Center and the University of Wisconsin also investigated technology in topology and control. All three contractors, as well as the University of Wisconsin, concluded at the end of the Phase I study, which included some critical laboratory work, that $0.1-\mathrm{kg} / \mathrm{kW}$ megawatt $\mathrm{DC} / \mathrm{DC}$ converters can be built. This is an order of magnitude lower specific weight than is presently available. A brief description of each of the concepts used to meet the ambitious goals of this program will be presented.
\end{abstract}

\section{INTRODUCTION}

The Strategic Defense Initiative (SDI), the Air Force, and NASA Lewis Research Center are proposing high power (hundreds of kilowatts to megawatts) space systems. SDI is interested in developing a lightweight power conditioning subsystem to drive high voltage radio frequency (RF) tubes used in RF accelerator-based weapon platforms. NASA Lewis is developing power system technologies for a manned lunar base. It has been estimated that 30 to 60 percent of the total power system mass can be attributed to the required power conditioning. Novel power conditioning designs will be required to reduce mass and prevent prohibitive launch costs thereby enabling the SDI and NASA Lewis systems mentioned above.

Presently, the lightest weight, most mature prime power components for SDI applications are combustion-driven turboalternators providing tens of $\mathrm{kV}$ at some $\mathrm{AC}$ frequency. For power conditioning, a high voltage step-up transformer and rectifier provide the $100+\mathrm{kV}$ DC power conditioning for the RF klystrode or klystron amplifier tubes. Issues related to vibration caused by 
large power system rotating machinery in space have yet to be resolved, however. An alternative prime power source is a hydrogen-oxygen alkaline fuel cell with hundreds to thousands of DC volts output. In this case, solid state amplifiers could provide the RF power for the accelerator.

Because high power RF tubes are more highly developed, and have so far been shown to be more efficient (thereby requiring less prime power fuel, a major mass driver), and since space platform vibration is unresolved, the feasibility of a hybrid power system is worth investigating. The hybrid system would consist of fuel cells for prime power, a high voltage output DC/DC converter, and RF tubes. In order for this approach to be an attractive option, the specific mass of the DC/DC converter must be less than $0.1 \mathrm{~kg} / \mathrm{kW}$.

The originally contemplated Space Station inverter design represents the state-of-the-art for power conditioning in space. Each $12.5-\mathrm{kW}$ inverter module has a specific mass of approximately $6 \mathrm{~kg} / \mathrm{kW}$. The Space Station is a low voltage, high current system, and is also a very conservative design for man-tended purposes. A more aggressive 1984 NASA Lewis design study using solid state switches available at that time had a specific mass of $2 \mathrm{~kg} / \mathrm{kW}$ (Baumann 1989). Clearly, revolutionary advances in power conditioning designs will be required to enable the megawatt space power systems.

DC/DC power conversion topologies under consideration range from hard-switched to resonant types. A hard-switched converter chops the DC directly into a transformer. Capacitors may not be required provided that the switches can handle the voltage transients caused by the transformer

leakage inductance. Fully controllable switches are mandatory in a hard-switched converter to avoid the extra mass associated with forced commutation circuitry.

An alternative approach to the hard-switched converter design is a resonance based approach. In an earlier NASA Lewis study, the mass contribution from each component type in a 500-kW, $20-\mathrm{kHz}, 2-\mathrm{kg} / \mathrm{kW}$ resonant converter design was determined (Baumann 1989). The results showed that the weight distribution was 63 percent capacitors, 30 percent inductors, and 7 percent switches. The capacitors are oversized in order to handle the circulating resonance currents due to the high $Q$ of the circuit. Resonant converters have the advantage of providing natural commutation for switches.

The technology program described below includes both the topology and design of converters as well as the necessary improvements in components such as transformers, capacitors, inductors, and switches.

A preliminary report was given on this work at the 1990 IECEC meeting (Kraus et al. 1990). This present, later paper will include weights, efficiencies, and other information that was not available at the time of the earlier presentation.

\section{The Program}

With the above points in mind, SDIO, the Air Force, and NASA Lewis initiated an ambitious joint program of contractors and NASA Lewis researchers. The SDI is the primary funding source for this effort, with the Air Force Wright Research and Development Center and NASA Lewis managing the contracts and performing supporting inhouse research. The technical goal of the 
contracted efforts is the development of a DC/DC converter with total power handling capability of $1 \mathrm{MW}$ and specific mass of $0.1 \mathrm{~kg} / \mathrm{kW}$. Other parameters of the system are to include:

- Input voltage range 500 to $5000 \mathrm{~V} \mathrm{DC}$;

- Output voltage $100 \mathrm{kV} \mathrm{DC}$;

- Fault tolerance: energy discharged into a load in event of a fault to be only a few tens of Joules;

- Minimum operating duration $1000 \mathrm{~s}$;

- Output voltage regulation less than 1 percent;

- Resistive load of 10 to $100 \mathrm{k} \Omega$, to simulate an RF tube such as a klystrode or klystron.

Three contractors (Hughes, 2 contracts, General Electric with Maxwell as a subcontractor) have completed the first phase of a proposed two phase multi-year program. During Phase I, the conceptual design of a DC/DC converter was completed, including supporting analyses and hardware experiments. If funding is available, a single contractor will be selected for Phase 2 to develop and test the required components and then integrate them into a complete megawatt system.

Hughes designed a hard-switched, square wave DC/DC converter. The switches at the input were Hollotron gas switches chopping $5 \mathrm{kV}$ DC input at $20 \mathrm{kHz}$ into a transformer/rectifier. The Hollotron uses a thermionic hollow cathode to provide the conductive plasma in a background of static xenon gas (Zwass et al. 1990). The Hollotron will have 10 to $20 \mathrm{~V}$ forward voltage drop. The switch rise- and falltimes have been demonstrated at less than $1 \mu \mathrm{s}$. A uniform $2 \mathrm{~A} / \mathrm{cm}^{2}$ anode current density has also been demonstrated in a small scale switch. One of the key development issues will be in scaling the Hollotron to much higher total currents $(>200 \mathrm{~A})$.

It should be noted that the Hollotron is expected to have both high temperature operating characteristics and radiation resistance much higher than that of semiconductor switches, even though these characteristics were not part of the present program requirements.

The Hughes transformer/rectifier design is derived in part from a previous program with the Army to design a lightweight multi-megawatt three phase transformer for tank applications. In a high voltage, square wave transformer, the need for insulation can lead to geometrical designs that induce a high leakage inductance. A high leakage inductance in conjunction with a long rise time results in a high ripple and high switch losses. The switching transients may then have to be snubbed by capacitors.

In order to avoid the need for capacitive snubbing, Hughes has created a transformer design with minimum leakage inductance. A low power version of their design has validated the circuit modeling for the design approach. The output of the full size transformer should have $<2 \mu \mathrm{s}$ rise- and falltimes, 10 percent overshoot, and 1 percent droop. The size of the entire unit (switches, transformer, and rectifier stacks) should fit into a volume of approximately $40000 \mathrm{~cm}^{3}\left(0.04 \mathrm{~m}^{3}\right)$.

The converter was designed to operate with static oil cooling initially held at $-40{ }^{\circ} \mathrm{C}$. After $1000 \mathrm{~s}$ of operation, the adiabatic temperature rise within the system will result in a transformer hot spot temperature below $160^{\circ} \mathrm{C}$ and the temperature of the Hollotrons will approach $200^{\circ} \mathrm{C}$. For details of design, circuit modelling, and low power circuit verification, see (Zwass et al. 1991). 
Table 1 lists calculated individual components weight, losses and the resulting overall system efficiency and weight. Table 2 compares the system design goals with the calculated data.

TABLE 1. Square Wave Converter Weight/

Losses/Efficiency.

\begin{tabular}{|c|c|c|}
\hline Component & Weight (kg) & Losses (W) \\
\hline Core & 15.0 & 880 \\
\hline Primary windings & 1.8 & 1800 \\
\hline Secondary windings & 2.0 & 1300 \\
\hline Rectifiers & 23.0 & 3200 \\
\hline Hollotron and driver & 9.3 & 18300 \\
\hline Dielectric fluid & 22.8 & 10 \\
\hline Hardware & 2.3 & \\
\hline L.V. terminal & 0.5 & \\
\hline H.V. terminal & 1.5 & \\
\hline Insulation & 5.6 & \\
\hline Housing & 11.0 & \\
\hline Total & 94.8 & 25490 \\
\hline Efficiency & 97.5 percent & \\
\hline
\end{tabular}

TABLE 2. 1 Megawatt T/R - Hollotron Unit Design Goals and Calculated Design Data.

\begin{tabular}{lll}
\hline Design Parameter & Design Goal & Calculated Design Data \\
\hline Input voltage & $5000 \mathrm{~V} \mathrm{DC}$ & $5000 \mathrm{~V} \mathrm{DC}$ \\
Output voltage & $100 \mathrm{kV}$ at $10 \mathrm{~A}$ & $100 \mathrm{kV}$ at $10 \mathrm{~A}$ \\
Cycle to cycle - voltage stability & \pm 1.0 percent $\mathrm{rms}$ & $\leq 1.0$ percent $\mathrm{rms}$ \\
Frequency & & $20 \mathrm{kHz}$ \\
Rectifiers & & $25 \mathrm{kV}$ at $10 \mathrm{~A}$ \\
Size & Minimum (in cm) & XFMR $=41.9 \times 31.7 \times 21.6$ \\
& & RECT $=27.4 \times 5.3 \times 9.6$ \\
Weight & & Hollotron $=8.4 \times 18.8 \mathrm{OD}$ \\
Flux density & $<0.1 \mathrm{~kg} / \mathrm{kW}$ & $95 \mathrm{~kg}(0.095 \mathrm{~kg} / \mathrm{kW})$ \\
Total losses & -- & $5 \mathrm{kgauss}$ \\
Efficiency & -- & $25490 \mathrm{~W}$ \\
Operating time & -- & $97.5 \mathrm{percent}$ \\
Ambient temperature & $16 \mathrm{~min}$ & $16 \mathrm{~min}$ \\
\hline
\end{tabular}

In operation, the output voltage and current are monitored to provide feedback for controlling the FET switches that trigger the Hollotrons. To vary the output power, the switches are pulse-width 
modulated. Pulse-width modulation of the scaled down, low power version of the transformer did not affect the risetime, falltime, or overshoot of the output.

GE and Maxwell Laboratories were teamed to develop resonance based converters with assistance from Harris Corporation in switching. GE and Maxwell provided key components (switches and capacitors) for each other, while developing their own circuit topologies in parallel. The GE topology is based on a series resonant, transformer linked topology that will be switched above the resonant frequency (superresonant operation). Maxwell investigated a transformerless converter using only reactive components.

The $5 \mathrm{kV}$ input to the GE converter will be switched at 20 to $40 \mathrm{kHz}$, and the Maxwell converter will be switched at $50 \mathrm{kHz}$ using MOS Controlled Thyristors (MCT). Up to four 100 A MCT devices will be paralleled in a switch module for current handling. Because each device will have a holdoff voltage of 1000 to $1600 \mathrm{~V}$, seven to ten modules will be stacked in series. Extensive computer modelling to determine the current and voltage sharing characteristics of the switch array was done. Preliminary results have shown a forward drop of approximately $1.2 \mathrm{~V}$ across each device. The turn-on time is estimated to be $<1 \mu \mathrm{s}$, and the turnoff time $<2 \mu \mathrm{s}$. Fast turnoff diodes will be connected in anti-parallel with the MCTs to carry the current during the switch intervals. Due to the inherent soft-switching of the super-resonant approach, lossless capacitive snubbers can be used.

In a series resonant converter with high voltage step-up, it is important to control the leakage inductance and the reflected $\mathrm{AC}$ capacitance through the transformer to avoid changes in the resonant frequency. To reduce the output power, the switching frequency can be increased. Phase modulation then extends the dynamic range of the system.

Maxwell uses a topology where only inductors and capacitors are used for voltage gain. A voltage fed topology is used. By cascading the stages, the total voltage gain is the product of the individual stages. Maxwell has determined that a single stage gain of $<10$ will work best for this application.

A significant fault tolerant characteristic of the transformerless converter is that less than $25 \mathrm{~J}$ is stored in the circuit. This also means that the converter can build up to the operating level of $1 \mathrm{MW}$ in a few cycles. Pulsed operation of the converter is then possible (as long as pulse shape is not critical to the load) by turning the converter on and off.

The gain versus frequency transfer function of the converter is such that the desired center frequency of operation lies between two poles; the output voltage of the converter is then easily controlled by varying the inverter frequency. The converter can also be pulse width modulated. By varying the conduction time of the inverter switches, the energy delivered to the converter is limited, thereby controlling the output voltage and current.

From a component point of view, the inductor design trade-off is an important element in determining maximum efficiency and power density. A Brooks coil minimizes weight, but stray magnetic fields produced may induce losses with the interaction of nearby metallic surfaces. Toroidal inductors limit stray magnetic flux, but increase weight.

Material selection and sizing for the resonant capacitors is based on the total $\mathrm{kVAs}$ of power handling required. Polypropylene was chosen as the dielectric due to its high dielectric strength, 
low dissipation factor, and flat temperature coefficients of capacitance and dissipation. In order to minimize the size of the $100 \mathrm{kV}$ filter capacitors, the dielectric must have a high dielectric constant and a high breakdown strength. Monoisopropyl biphenyl was selected as the dielectric impregnating fluid.

A previous Maxwell program with NASA developed $600 \mathrm{~V} \mathrm{rms,} 10$ and $40 \mathrm{kHz}$ AC capacitors with a specific mass of $0.04 \mathrm{~kg} / \mathrm{kVAr}$. This technology achievement won an IR100 Award in 1983. Significant technical achievement since then has shown the feasibility for a factor of four improvement in power density.

A $10 \mathrm{~kW}, 60 \mathrm{kV}$ output voltage transformerless converter has been successfully built and tested by Maxwell on another program. High power scaling and thermal management are the key issues to be resolved. Cooling the inductors is important to maintain a high current density for low weight magnetics. This conflicts with the requirement to keep the capacitors above approximately $-20{ }^{\circ} \mathrm{C}$, a lower bound for some insulation and semiconductor materials. More complete information is given in the GE - Maxwell final report (Park and Cooper 1991).

Table 3 gives weight and efficiency comparisons between the GE superresonant topology of DC/DC converter and the Maxwell resonant transformer topology. Table 4 points up the difference in specific weight as power is increased from 1 to $10 \mathrm{MW}$ for the Maxwell resonant transformer topology.

TABLE 3. System Comparison of Superresonant and Resonant Transformer Topologies.

\begin{tabular}{|c|c|c|c|c|}
\hline \multirow[t]{3}{*}{ Converter Component } & \multicolumn{4}{|c|}{ System Approach } \\
\hline & \multicolumn{2}{|c|}{ Superresonant } & \multicolumn{2}{|c|}{ Resonance Transformer } \\
\hline & $\begin{array}{c}\text { Mass } \\
(\mathrm{kg})\end{array}$ & $\begin{array}{r}\text { Loss } \\
(\mathrm{W})\end{array}$ & $\begin{array}{c}\text { Mass } \\
(\mathrm{kg})\end{array}$ & $\begin{array}{r}\text { Loss } \\
(\mathrm{W}) \\
\end{array}$ \\
\hline Input fuse & 1.0 & 10 & 1.0 & 5 \\
\hline DC input filter capacitor & 3.0 & 5 & 2.0 & $\mathbf{5}$ \\
\hline Inverter & 8.0 & 42400 & 8.0 & 40000 \\
\hline Power circuit & $44.0^{\mathrm{a}}$ & $12236^{\mathrm{a}}$ & 52.7 & 101400 \\
\hline DC output filter capacitor & 14.0 & 60 & 7.4 & 1 \\
\hline DC output crowbar & 2.0 & $\mathbf{0}$ & 1.8 & 0 \\
\hline Control electronics & 0.5 & ----- & 2.6 & 5000 \\
\hline Cooling system & 10.0 & 1000 & 3.3 & --.--- \\
\hline Component support structure & 4.5 & ----- & 1.0 & ------ \\
\hline Envelope enclosure $\left(\mathrm{m}^{3}\right)$ & $1.5(0.28)$ & $-\cdots$ & $4.0(0.62)$ & ב-.--- \\
\hline $\begin{array}{l}\text { Total system } \\
\text { Specific mass }\end{array}$ & 88.5 & 55711 & 83.8 & 146411 \\
\hline Specific mass & $0.0885(\mathrm{~kg} / \mathrm{kW})$ & & $0.0838(\mathrm{~kg} / \mathrm{kW})$ & \\
\hline System efficiency & 94.4 percent & & 87.2 percent & \\
\hline
\end{tabular}

${ }^{a}$ Includes the resonant inductor and capacitor, transformer and high voltage output rectifier. 
Table 4. Resonance Transformer Specific Mass.

\begin{tabular}{lcc}
\hline \multicolumn{1}{c}{ Component } & $1 \mathrm{MW}(\mathrm{kg})$ & $10 \mathrm{MW}(\mathrm{kg})$ \\
\hline Input fuse & 1.0 & 10.0 \\
Input filter capacitor & 2.0 & 20.0 \\
Inverter & 8.0 & 40.0 \\
Resonance transformer capacitors & 20.8 & 187.2 \\
Resonance transformer inductors & 16.0 & 144.9 \\
Voltage multiplier capacitors & 12.6 & 38.4 \\
Diode stacks & 3.3 & 6.6 \\
Filter capacitor & 7.4 & 66.6 \\
Crowbar circuit & 1.8 & 3.6 \\
Regulator circuit & 2.6 & 26.0 \\
Cooling plena & 3.3 & 10.0 \\
Component supports & 1.0 & 10.0 \\
Envelope & 4.0 & 12.0 \\
& & \\
Totals & 83.8 & 575.3 \\
& $0.0838 \mathrm{~kg} / \mathrm{kW}$ & $0.0575 \mathrm{~kg} / \mathrm{kW}$ \\
\hline
\end{tabular}

The research and development work at the University of Wisconsin under SDIO funding and NASA/AF management pursued topologies for DC/DC conversion using "quasiresonant" or "soft" switching. (Divan and Kheraluwala 1990). Here topologies were investigated, with the one chosen being a single phase dual active bridge. In this topology, both the input and output are switched (for example, diode rectifiers on the output were replaced by switches). A $50 \mathrm{~kW}$ breadboard was built with a specific weight of $0.243 \mathrm{~kg} / \mathrm{kW}$ and an efficiency of 84 to 90 percent using available IGBTs as switches with an input voltage of $200 \mathrm{~V}$ and an output voltage of $1600 \mathrm{~V}$. A projected specific weight of a $1 \mathrm{MW} \mathrm{DC/DC} \mathrm{converter,} \mathrm{using} \mathrm{MOS} \mathrm{controlled} \mathrm{thyristors} \mathrm{as}$ switches and multilayer ceramic capacitors is 0.075 to $0.08 \mathrm{~kg} / \mathrm{kW}$ with an efficiency of 96 percent (Divan and Kheraluwala 1990).

Looking forward to the time when megawatt type power system would need to be tested, NASA Lewis in an in-house program investigated losses in inverters and especially the use of pulse testing techniques for large DC/DC converters. In this method, full power electric testing is done over a millisecond time range, ( 1 to 100 pulses of 20 to $50 \mathrm{kHz}$ ) followed by a relatively long offtime. The converter thus runs at full power, for a short time, so that equilibrium full power currents and voltages can be measured, without generating full thermal power and without the need of large scale, expensive high power facilities. The power for the testing is supplied from a relatively small capacitor bank, whose charging power source is only of the order of a $\mathrm{kW}$ for doing megawatt testing (Baumann et al. 1990).

\section{CONCLUSIONS}

In a phase I effort three contracts and a university grant were used to develop the base of very lightweight high power (megawatt) DC/DC converters. Projected weight and efficiencies are given in Table 5. 
TABLE 5. Projected Weight and Efficiencies of Different Approaches to Megawatt DC/DC Converters.

\begin{tabular}{llll}
\hline \multicolumn{1}{c}{ Topology of converters } & \multicolumn{1}{c}{ Company } & Specific weight & \multicolumn{1}{c}{ Efficiency } \\
\hline Square wave hard switched & Hughes & $0.095 \mathrm{~kg} / \mathrm{kW}$ & 97.5 percent \\
Superresonant & GE & $0.0885 \mathrm{~kg} / \mathrm{kW}$ & 94.4 percent \\
Resonant transformer & Maxwell & 0.0838 & 87.2 percent \\
Dual active bridge & University of Wisconsin & $0.08 \mathrm{~kg} / \mathrm{kW}$ & 96 percent \\
Dual active bridge & $\begin{array}{l}\text { University of Wisconsin } \\
(50 \mathrm{~kW} \text { actual) }\end{array}$ & 0.243 & 84 to 90 percent \\
\hline
\end{tabular}

All of the organizations involved projected (theoretical) specific masses of megawatt power DC/DC converters of $0.1 \mathrm{~kg} / \mathrm{kW}$ or less. No full scale hardware has yet been built and tested, however. Also, the weights given do not include the heat rejection system once the heat has been transferred to the box surrounding the converter.

Primary technology needs in the megawatt converter technology area, beside direct hardware demonstration, are in switch development.

\section{Acknowledgments}

Many people and organizations have contributed to this work. First in importance is the funding and technical interest and support of SDIO and Richard Verga, including Mitch Nikolitch, Jim Sarjeant, Bill Dunbar, and Scott Gilmour at W.J. Schafer Assoc. Others involved include the Air Force at WPAFB with Capt. Neal Harold, Pete Lamm, Erick Ruchstadter, and Dave Massie; GE with John Park, Mike Schutton, and William McMurray; Harris Corporation with Vic Tempil, Tahagami Nakagama, and Don Watrous; Maxwell with Randy Cooper and Wayne White; Hughes at El Segundo with John Peters, Harry Ashe, and Joe Zwass; Hughes at Malibu, R.L. Poeschel, D. Goebel, and R.W. Schumacher; Unversity of Wisconsin, Deepakraj Divan and Moustansir Kheraluwala; and NASA LeRC, Joe Sovie, John Smith, Robert Bercaw, and Robert King.

\section{$\underline{\text { References }}$}

Baumann, E. (1989) "Power Conditioning Techniques," NASA TM-102577 presented at the Neutral Particle Beam Technology Symposium, Monterey, CA, June 1989.

Baumann, E.D., I.T. Myers, and A.N. Hammoud (1990) "Electrical Characterization of a Mapham Inverter Using Pulse Testing Techniques.” 25 IECEC, Reno, NV, 12-17 August 1990, pp. 423.

Divan, Deepakraj M. and M.H. Kheraluwala, (1990) High Power Density DC/DC Converters for Aerospace Applications, final report on grant NAG 3-804, University of Wisconsin, Madison, WI. 
Kraus, R., I. Myers, and E. Baumann (1990) “Light Weight, High Power High Voltage DC/DC Converter Technologies," 25 IECEC, Reno, NV, 12-17 August 1990, pp. 380.

Poeschel, R.L., D. Goebel, and R.W. Schumacher (1991) Hollotron Switch for Megawatt Lightweight Space Inverters, NASA CR-187083, Hughes Research Laboratories, Malibu, CA.

Park, J.N. and R. Cooper (1991) High Power Converters for Space Applications, NASA CR-187116, GE Corporate Research and Development, Schenectady, NY and Maxwell Laboratories, Inc., San Diego, CA.

Zwass, S., H. Ashe, and J.W. Peters (1991) High Reliability Megawatt Transformer/Rectifier, NASA CR-187079, Hughes Aircraft Co., El Segundo, CA. 


\begin{tabular}{|c|c|c|c|}
\hline \multicolumn{3}{|c|}{ REPORT DOCUMENTATION PAGE } & $\begin{array}{l}\text { Form Approved } \\
\text { OMB No. 0704-0188 }\end{array}$ \\
\hline \multicolumn{4}{|c|}{ 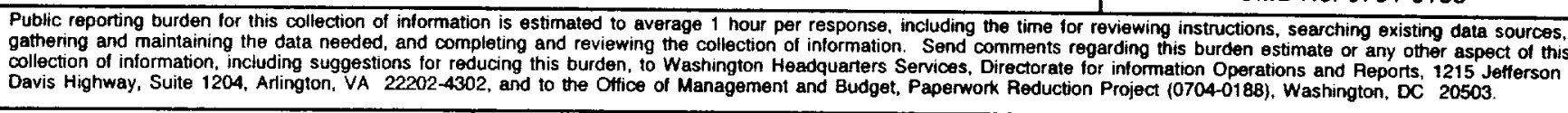 } \\
\hline 1. AGENCY USE ONLY (Leave blank) & 2. REPORT DATE & \multicolumn{2}{|c|}{$\begin{array}{l}\text { 3. AEPORT TYPE AND DATES COVERED } \\
\text { Technical Memorandum }\end{array}$} \\
\hline \multicolumn{3}{|c|}{$\begin{array}{l}\text { 4. TITLE AND SUBTITLE } \\
\text { Multi-Megawatt Inverter/Converter Technology for Space } \\
\text { Power Applications }\end{array}$} & \multirow{2}{*}{$\begin{array}{l}\text { 5. FUNDING NUMBERS } \\
\text { WU }-506-41-41\end{array}$} \\
\hline \multicolumn{3}{|c|}{$\begin{array}{l}\text { 6. AUTHOR(S) } \\
\text { Ira T. Myers, Eric D. Baumann, Robert Kraus, and Ahmad N. Hammoud }\end{array}$} & \\
\hline \multicolumn{3}{|c|}{$\begin{array}{l}\text { 7. PERFORMING ORGANIZATION NAME(S) AND ADDRESS(ES) } \\
\text { National Aeronautics and Space Administration } \\
\text { Lewis Research Center } \\
\text { Cleveland, Ohio } 44135-3191\end{array}$} & $\begin{array}{l}\text { 8. PERFORMING ORGANIZATION } \\
\text { REPORT NUMBER } \\
\text { E- } 6543\end{array}$ \\
\hline \multicolumn{3}{|c|}{ 9. SPONSORING/MONITORING AGENCY NAMES(S) AND ADDRESS(ES) } & $\begin{array}{l}\text { 10. SPONSORING/MONITORING } \\
\text { AGENCY REPORT NUMBER } \\
\text { NASA TM }-105307\end{array}$ \\
\hline \multicolumn{4}{|c|}{$\begin{array}{l}\text { 11. SUPPLEMENTARY NOTES } \\
\text { Prepared for the Ninth Symposium on Space Nuclear Power Systems sponsored by the Institute for Space Nuclear Power Studies, University of New Mexico, Albuquerque, } \\
\text { N. Mexico, January 12-16, 1992. Ira T. Myers and Eric D. Baumannn, NASA Lewis Research Center. Rober Kraus, W.J. Schafer Associates, Inc., 1901 N. Fort Myer } \\
\text { Drive, Arlington, Virginia 22209. Ahmad N. Hammoud, Sverdrup Technology, Inc., Lewis Research Center Group, 2001 Aerospace Parkway, Brook Park, Ohio } 44142 \\
\text { (work funded by NASA Contraci NAS3-25266). Responsible person, Ira T. Myers. (216) 433-6116. }\end{array}$} \\
\hline \multicolumn{3}{|c|}{\begin{tabular}{l|} 
12a. DISTRIBUTION/AVAILABILITY STATEMENT \\
Unclassified-Unlimited \\
Subject Category 33
\end{tabular}} & 12b. DISTRIBUTION CODE \\
\hline \multicolumn{4}{|c|}{$\begin{array}{l}\text { 13. ABSTAACT (Maximum 200 words) } \\
\text { Large power conditioning mass reductions will be required to enable megawatt power systems envisioned by the } \\
\text { Strategic Defense Initiative, the Air Force and NASA Lewis Research Center. Phase I of a proposed two phase } \\
\text { interagency program has been completed to develop an } 0.1 \mathrm{~kg} / \mathrm{kW} \text { DC/DC converter technology base for these future } \\
\text { space applications. Three contractors, Hughes, General Electric (GE), and Maxwell were Phase I contractors in a } \\
\text { competitive program to develop a megawatt lightweight DC/DC converter. Researchers at NASA Lewis Research } \\
\text { Center and the University of Wisconsin also investigated technology in topology and control. All three contractors, } \\
\text { as well as the University of Wisconsin, concluded at the end of the Phase I study, which included some critical } \\
\text { laboratory work, that } 0.1-\mathrm{kg} / \mathrm{kW} \text { megawatt DC/DC converters can be built. This is an order of magnitude lower } \\
\text { specific weight than is presently available. A brief description of each of the concepts used to meet the ambitious } \\
\text { goals of this program will be presented. }\end{array}$} \\
\hline \multirow{2}{*}{\multicolumn{3}{|c|}{$\begin{array}{l}\text { 14. SUBJECT TERMS } \\
\text { Voltage converters (DC to DC); Power converters; Aerospace systems; Spacecraft } \\
\text { electronic equipment }\end{array}$}} & 15. NUMBER OF PAGES \\
\hline & & & 16. PRICE CODE \\
\hline $\begin{array}{l}\text { 17. SECURITY CLASSIFICATION } \\
\text { OF REPORT } \\
\text { Unclassified }\end{array}$ & $\begin{array}{l}\text { 18. SECURITY CLASSIFICATION } \\
\text { OF THIS PAGE } \\
\text { Unclassified }\end{array}$ & $\begin{array}{l}\text { 19. SECUPITY CLASSIFCATIOI } \\
\text { OF ABSTAACT } \\
\text { Unclassified }\end{array}$ & 20. LIMITATION OF ABSTRACT \\
\hline NSN 7540-01-280-5500 & & & $\begin{array}{l}\text { Standard Form } 298 \text { (Rev. 2-89) } \\
\text { Prescribed by ANSI Std. Z39-18 } \\
298-102\end{array}$ \\
\hline
\end{tabular}

